\title{
Multinational firms and the extractive sectors in the 21st century: can they drive development?
}

Article

Accepted Version

Creative Commons: Attribution-Noncommercial-No Derivative Works 4.0

Narula, R. (2018) Multinational firms and the extractive sectors in the 21st century: can they drive development? Journal of World Business, 53 (1). pp. 85-91. ISSN 1090-9516 doi: https://doi.org/10.1016/j.jwb.2017.09.004 Available at https://centaur.reading.ac.uk/72618/

It is advisable to refer to the publisher's version if you intend to cite from the work. See Guidance on citing.

To link to this article DOI: http://dx.doi.org/10.1016/j.jwb.2017.09.004

Publisher: Elsevier

All outputs in CentAUR are protected by Intellectual Property Rights law, including copyright law. Copyright and IPR is retained by the creators or other copyright holders. Terms and conditions for use of this material are defined in the End User Agreement.

www.reading.ac.uk/centaur

\section{CentAUR}


Central Archive at the University of Reading

Reading's research outputs online 


\title{
Multinational firms and the extractive sectors in the 21st century: can they
}

\section{drive development?}

\section{Journal of World Business, forthcoming}

\author{
Rajneesh Narula
}

Professor of International Business Regulation

Director of the John Dunning Centre for International Business

Henley Business School, University of Reading, United Kingdom, RG6 6UD

\begin{abstract}
Historically, extractive sector MNEs have been seen as an obstacle to sustainable development, because they operated in enclaves with limited local engagement. Importsubstitution policies aimed to increase the local benefits of these resources, restricting FDI. Since liberalisation, extractive MNEs have re-engaged with developing countries through looser governance structures with greater potential for linkages. Despite the potential, few host countries have seen meaningful MNE-led development because of weak domestic firms and poor location advantages. New MNEs from emerging economies have not shown a greater propensity to local linkages. Only countries that have continued to invest in location advantages have seen substantial benefits.
\end{abstract}

Acknowledgements: I would like to thank Ana Botella of the University of Valencia for her research assistance and comments on the various drafts. I am also indebted to Grazia Santangelo, Daniel Shapiro, Elisa Giuliani and Lou Anne Barclay for their insightful feedback.

Keywords: sustainable development, MNEs, linkages, emerging economies, extractives, natural resources, infrastructure, enclaves. 


\section{Multinational firms and the extractive sectors in the 21st century: can they drive development?}

\section{Introduction}

It is a central characteristic of a developing country that natural resource sectors dominate its economic structure, and it is the gradual shift away from these activities (towards manufacturing and services) that is considered to be the hallmark of economic development. Indeed, subsistence societies rely almost entirely upon on unmodified 'natural' inputs associated with land (including subsoil resources, vegetation and animals) and unskilled human labour. Development implies an increasing utilization of capital, which I will use in in the sense preferred by Adam Smith, as physical assets, machines and people, and not (only) in the narrow sense of capital as money ${ }^{1}$. In today's parlance, this is what is known as knowledge capital, and refers to the capacity to add value to naturally occurring inputs. Natural assets are enhanced by transforming these natural assets into 'created assets' (Dunning 1993) through the adding of value, either through organisational skills, or transforming them through production or processing. Economic development springs from reinforcing the efficacy of these transformations within the economy. The proof of a successful development strategy is often taken to be a natural resource sector that is no longer the primary sector. In this paper I emphasise the extractive sector, although the principles I look to are broadly applicable across all branches of the primary sector, except that extractive activities are resources that are non-renewable, and are therefore in fixed supply. They have the capacity to provide returns well in excess of their cost of production (referred to as 'rents'). Rents from extractive sectors have the potential to create the basis for further economic activity in other (renewable) industries, therefore acting as driver for sustainable development. I use the term 'sustainable development' in a narrower sense than the currentlypopular (but unachievable) 'Sustainable Development Goals' to mean economic development that does not excessively depend upon natural resources or on volatile commodity prices, and is therefore not interrupted by the vagaries of commodities markets. Note that sustainability and sustainable development are different concepts: the former term being popularly used more narrowly describe the use of natural resources without depletion in order to maintain an ecological balance.

\footnotetext{
${ }^{1}$ Money is, arguably, a natural asset. Its possession per se provides no rents, it is through its astute use (buying a property or machinery, investing in stocks, that generates rents, but this requires knowledge.
} 
At the heart of the vitality (or its lack) of the extractive sector as an engine for sustainable development is the MNE. The MNE (or 'foreign capital' as it was referred to in the earlier development literature ${ }^{2}$ ) and the resource sector have a strange and convoluted history. The MNE has been much derided in the dependency theory literature as generating too few benefits for the host, and causing structural distortions in the local economy, as well negatively impacting its political processes (Moran 1978). MNEs had a habit of internalising the complete value chain and creating enclaves around their facilities that had few linkages or spillovers locally (see Prebisch 1950, Girvan 1970, 1973). This buttressed the view that the MNE in the extractive sector was an obstacle to development.

As a response, many countries adopted an import substituting, inward-looking policy orientation. Where implemented diligently, this led to the growth in some countries of a variety of domestic firms that had the competences to extract resources without MNE intervention, a cohort of suppliers, and a variety of industries further upstream that utilised these extractive outputs. Brazil and India are good examples of countries which have succeeded in this regard, developing pockets of excellence in several sectors. This has led to a new breed of MNEs (often the progeny of import-substitution) competing with traditional MNEs. In Brazil, for example, a successful industrial network developed around Petrobras (Dantas and Bell 2011), as well as in the mining sector around Vale (see Rodrigues and Dieleman, this issue). In the majority of developing countries, however, domestic sectors failed to reach critical mass.

Since the 1990s, a concatenated change in the organisation of economic activity due to globalisation has also seen a change in the organisation of extractive sector activity, and the attitude of host countries. Economic liberalisation and a new outward policy orientation has pushed states towards greater engagement, reducing MNE-government conflict (Narula and Dunning 2000, Mullner and Puck, this issue). At the firm level, extractive sector MNEs no longer seek to internalise all value-adding, which in principle has meant more opportunities for linkages with the domestic sector. There is also greater awareness in host countries of the opportunities the extractive sector can provide, and concurrently greater pressures for corporate social responsibility (CSR) from civil society, regulatory agencies and other stakeholders, in both developed and developing countries.

\footnotetext{
${ }^{2}$ The term has its roots in the work of Karl Marx, but is best developed by Rosa Luxemburg (2003). See Rasiah (1995) for a useful discussion.
} 
In principle, this new dispensation is supposed to increase the potential benefits through linkages with host country firms, as well as through competition and demonstration effects. But how much do developing countries really benefit (in development terms) from these new realities? I argue that much depends upon the strength of the domestic firm sector, and the capacity of local actors with whom to link. This is an extension of the vicious cycle of poverty: Domestic incapacity is a function of the weakness in the stock of location advantages. The more underdeveloped a country is, the weaker the location (L) advantages, and this normally implies a weak domestic firm sector (Dunning and Narula 1996, Criscuolo and Narula 2008). FDI-led development requires a certain minimum threshold of $\mathrm{L}$ advantages to ensure that domestic firms are able to survive and thrive. Ironically, when there is poor domestic firm capacity, MNEs are obliged to internalise activities that they would have preferred to outsource. Beyond that, sustainable development also requires diversification beyond the immediate extractive sector MNE's value chain. A nascent domestic sector (both firms and the associated L advantages) outside the extractive sector in required. Without this, the likely outcome is again the overspecialisation that marked the preglobalisation era.

\section{Development and the extractive sector: the background}

The limitations of natural resources as a driver of development, and the consequent attention paid to upgrading the secondary and tertiary sectors has its roots in the work of Schumpeter, and more formally Prebisch (1950), Singer (1950) and Lewis (1954). To simplify a complex set of arguments, natural resource outputs are commodities whose prices are volatile, which means growth also becomes cyclical. An economy that diversifies away from the primary sector into the relatively more stable manufacturing and services sector acts as a 'valve' for surplus labour and ensures more stable incomes. Coercing a single-sector economy towards a more balanced one, forms the dogma upon which much of development strategy rests.

Resource wealth has not always proven to be a blessing. Auty (1993) introduced the term 'resource curse' to describe countries that underperform despite being resource-rich. Work by Sachs and Warner $(1995,1997)$ found that natural resource dependence had a significant negative effect on GDP per capita growth (controlling for initial income, investments in 
physical and human capital, trade openness, and rule of law) $)^{3}$. Failure to diversify away from extractive sectors, for example, by utilizing the rents for current consumption is equivalent to the liquidation of a country's capital stock (World Bank 2011). The majority of the less developed countries have failed to benefit from resource rents ${ }^{4}$ (Venables 2016). Many of these countries show growth which is closely mirrors volatile commodity prices, and therefore, by its very definition, is unsustainable. Table 1 provides some data on a selection of resource-rich countries. These data indicate that in many cases they matter more than they did 25 years previously ${ }^{5}$. Table 1 also illustrates the volatility, with high rents in many extractive industries attributable to the commodity boom that peaked about 2010.

\section{****Table 1 about here ${ }^{* * *}$}

Resource abundance is also associated with the 'Dutch Disease', which describes the propensity for resource-rich countries to over-specialise in resource extraction while neglecting tradable activities from other sectors of the economy. Investments in locationspecific assets (human capital, infrastructure) are diverted away from other value-adding activities to support the resource sector. Harding and Venables (2016) find that every \$1 of resource exports decreases non-resource exports by 74 cents, while also increasing imports by 23 cents. They also find that domestic manufacturing tends to be crowded-out by resource activity to a higher degree than agriculture or services. Given the time-constrained nature of subsoil assets, the shrinkage of the rest of the economy can have dire consequences for sustained development.

Our current understanding of the development benefits associated with economic activity is greatly shaped by the pioneering work on linkages by Hirschman $(1958,1977,1981)$. This body of work looks at the opportunities that derive to the larger economy from the activity of a given economic actor. This can take the form of direct and indirect engagement immediately outside the operations of the focal unit. Hirschman proposed three types of linkages. The most basic (and least useful) set of linkages are fiscal linkages. Fiscal linkages are rents which the country accrues in the form of taxes, royalties, revenues, and local taxes on the incomes of employees. The second type are consumption linkages which derive from

\footnotetext{
${ }^{3}$ More recent work has determined that the nature of the resource curse is much more nuanced. See Shapiro et al, this issue)

${ }^{4}$ Failure to benefit from resource abundance is not a fait accompli. Malaysia, Botswana and Chile are among the few developing countries that have avoided the resource curse.

${ }^{5}$ It is as much a result of the collapse of the unsustainable manufacturing sectors, as about the improved competitiveness of the resource sector.
} 
demand by the focal firm for the output of other actors in the same country, and these can be in the form of services provision and indirect demand for local goods and services. The third type are production linkages, which can be forward linkages (other actors adding value to the commodity by processing it) and backward (producing inputs to be utilised in the extraction of the commodity). Production linkages can exist within the extractive sector along the same value chain (intra-industry), but they can also be inter-industry (horizontal) (Kaplinsky et al 2011). For sustainable development inter-industry linkages are essential. The generation of new industries - whether these are support industries (such as banks, or transportation and logistics companies) which have multiple potential users across sectors, or horizontal effects that initiate new value chains in other, non-extractive sectors (Kaplinsky et al 2011).

There is a fairly recent literature that indicates that the Dutch disease and lower rates of growth are not inevitable outcomes of having a strong comparative advantage in the extractive sector. Ville and Wicken (2012) point to the case of Norway and Australia as having managed sustained growth over a long period. Similar observations can be made for the US and many European nations at earlier epochs in the history (Wright 1990). This view suggests that it is possible to create a dynamic set of industries and activities around a resource-rich country's 'core' asset. These sets of related and interlinked industries involve higher value added activities, where price changes are offset by productivity improvements, through technological innovation, organisational changes and increased efficiencies in collaboration with complementary actors. Indeed, the evidence is convincing that it is not the presence of natural resources per se that leads to low growth rates, but the failure to utilise the rents to develop a location-specific set of complementary assets that support upgrading.

\section{'Foreign capital' and development - a chronological perspective}

The absence of growth from extractive sectors in the Prebisch-Singer perspective derived in part from the dominating role of foreign capital in extraction (nowadays refer to as FDI). The logic of this argument went as follows. Resource extraction is a highly capital-intensive exercise. Considerable ownership (O) advantages are needed to engage in extractive industries, and since the sector has a high scale- and capital-intensity, it is naturally oligopolistic, dominated as it is (was) by a handful for MNEs (Shapiro et al, this issue). 
Being a large actor is de rigueur, and as such these actors are either state-controlled (and/or formerly state-owned) or private MNEs with the particular financial, technological and human capital which provides them with distinct (and hard-to-copy) $\mathrm{O}$ advantages. The $\mathrm{O}$ advantages of these MNEs are fourfold, and have not changed over the last century or so:

1. They have the technological capability to access resources in locations that were previously extremely difficult to access, and/or to explore and extract more value from subsoil assets that weaker counterparts would have abandoned (Kraemer and van Tulder 2009). These technological assets are more about process technologies, and are a key source of competitiveness.

2. They possess an intricate knowledge of specialised markets and are able to organise themselves across borders within and between hierarchies as a result of superior abilities in coordinating a multitude of value chains in several locations.

3. They have deep pockets and access to financial capital by leveraging global capital markets (or the treasury of their home country), which permits them to negotiate longterm control of significant natural resources. Long-term concessions are necessary to recover the high sunk costs of extraction.

4. They have strong political connections both at home and in the host country.

Large extractive MNEs had (and continue to have) the capacity to dominate their host economy (especially the smaller, less developed countries with a single-sector focus (Girvan 1970). A typical extractive MNE may have global revenues that are equivalent to the GDP of many a host economy. They therefore have a natural capacity for regulatory capture, and this allowed for uneven distribution of rents that favoured the MNE (The same was often true for these MNEs in their home country).

These MNEs were vertically integrated and coordinated markets through quasi-hierarchies across borders, thereby influencing prices. Given these characteristics, this led to an asymmetric relationship between host (or home) and the MNE. MNEs in the extractive sector (mostly headquartered in the developed countries) had (and still have) the capacity to internalise imperfect markets on a global basis.

The principles of MNE-assisted development in the extractive sectors are no different from other sectors (UNCTAD 2007). There is need for a certain threshold level of L advantages to attract MNEs in the first instance; however the benefits from the FDI come from the degree to which they are embedded, and create direct and indirect effects in the local economy. In 
other words, benefits derive largely from the capacity of other collocated firms (domestic and foreign-owned) to establish (and deepen) linkages (Giroud 2012, Jindra et al 2009). When extractive operations are linked shallowly with other actors in the host economy, there are few obvious development effects beyond fiscal and consumption linkages. Linkages do not always happen spontaneously, they need to be developed, nurtured and promoted, and encouraged to expand both backwards and forward.

The creation of infrastructure that is multi-user and available to all at marginal cost is an important precondition for consumption and production linkages. Where infrastructure is highly specific to a specific user or sector, it limits the benefits to other sectors of the economy (and increases the enclave effect). Likewise, forward linkages also require complementary investments in L advantages, and a vibrant domestic firm sector. The viability of this approach depends on the wider capabilities and comparative advantage of the local economy.

\section{MNEs and the extractive sector: a drama in three parts}

The history of MNE engagement in the extractive sector can be seen as having three phases.

\section{Act I: the extractive MNE and rent extraction until the 1950s/60s}

The first proto-MNEs began as state-sanctioned chartered companies (e.g., the British, Dutch and French East India companies) that de facto or de jure controlled the former European colonies in Latin America, Asia and Africa (Jones 2005). Their reputation for extracting maximum rents at the expense of the host country through ethically and morally dubious means defined the image of the MNE (and therefore the attitude) of many former colonies towards large MNEs (privately or publicly owned). Indeed, it is no exaggeration to say that the over-specialisation of many developing countries reflects the priorities from colonial period. Investments in the colonies were designed to extract resources for immediate export and subsequent processing and sale at home at the lowest possible cost (and possible reexport back to the colonies after processing). This often came at high social costs, which ignored traditional property rights and land usage, the forcible resettlement of indigenes, and the destruction of habitats ${ }^{6}$ (Girvan 1970, 1973, Barclay 2015).

\footnotetext{
${ }^{6}$ For an extreme perspective, see Rodney (1972)
} 
That benefits did not accrue from resource-intensive sectors along with a related attenuation of other 'traditional' economic activities (for instance, artisanal mining, cottage industries, agriculture) shaped the over-specialisation and accentuated the 'dual economy' nature of many developing countries, the duality being noted primarily for the disconnect between the two aspects (see for instance Yakovleva \& Vasquez, this issue). Duality was (and remains) a defining feature of less developed countries ${ }^{7}$. Development opportunities were (and are) constrained when both parts of the duality have an enclave character. The linkages between the two were intentionally weak in the colonial era, and in many cases have remained weakly linked (Levitt and Best 1975).

MNEs contributed to this enclave nature. Extractive sectors were often (but not always) associated with rural, geographically isolated locations. This often means (although it should not) a poorly developed infrastructure prior to the establishment of industrial-scale extraction. Basic infrastructure (roads, railways, electricity, potable water) are generally in poor condition or non-existent, and there is a dearth of skilled and semi-skilled workers (because such places rarely have schools). MNEs may build roads, schools, clinics, and essentially set up private infrastructure for their own use. The extent to which these are made available to the immediate local community is limited (Shapiro et al this issue). This creates a de facto physically isolated enclave with a high quality infrastructure. Communities outside the 'catchment area' received limited access to these resources. MNEs tended to utilise a high ratio of expatriates to local employees in technical and management jobs.

Indeed, Singer (1950) asserted that the commodities sector was intentionally designed by the MNE to have an enclave character, planned to facilitate the export of commodities and the reduction of the associated transportation costs. The opportunities for the further processing domestically, either for domestic use or for higher value added export, was rarely a consideration (Morris et al 2012). These characteristics were very much evident during much of the early $20^{\text {th }}$ century with large MNEs who internalised the rents from extraction through transfer pricing, and by performing much of the processing in their home countries. This negative image of the MNE was not enhanced by their abuse of their economic strength to affect the outcome of domestic politics to their own advantage.

\section{Act II: Import-substitution era and the extractive $M N E$}

\footnotetext{
${ }^{7}$ Formally developed by Lewis (1954). The nature of the duality having evolved over the years, the key principle being a strong resource-intensive sector and a less-developed knowledge-intensive one (Narula 2015).
} 
These circumstances - excessive rent extraction by MNEs, state capture, persistent underdevelopment - led to import-substitution policies in many developing countries by the 1950s. At the risk of oversimplifying a complex set of developments ${ }^{8}$, the doctrine of import substitution took hold in the post-World War II era, emphasised moving away from exporting primary commodities and importing manufactures, towards developing a domestic industrial base. Protection was undertaken through tariffs, exchange rate manipulation, quotas and exchange controls. They emphasised a reduced dependence on primary activities, as well as a concurrent wave of nationalisation of the assets of MNEs along with an emphasis on building up (new) domestically owned actors. Control of subsoil assets were transferred to these national champions (mainly state-owned), with a mandate to maximise local content, and to provide inputs for the nascent manufacturing sectors.

Import-substitution (IS) policies did lead to economic growth in most developing countries during the 1960s and the 1970s, although the anticipated expansion of domestic manufacturing did was by no means uniformly successful. IS schemes were not adjusted to reflect differences in comparative advantages, but sought to duplicate the same breadth of industrial sectors regardless of their initial specialisation and resource endowment.

There are two key outcomes from the IS-era (for our purposes). First, the nationalisation and/or emphasis on creating domestic actors and maximising local content created a new set of domestic actors in the extractive sector. Infant industry protection coupled with capital and technology from abroad (sometimes through joint ventures with traditional MNEs, in other cases through turn-key projects and the provision of technical experts) created a new set of actors. The largest domestic firms from India, Russia, China, Malaysia, and Brazil today are extractive firms that come from the IS era.

Second, a number of developing countries made concurrent investments in their location advantages, particularly in infrastructure and education. Indeed, many developing countries had built up a certain degree of absorptive capacity, and a small but impressive set of worldclass universities, research institutes and support industries. Development requires as a sine qua non a variety of key $\mathrm{L}$ advantages. The $\mathrm{L}$ advantages needed to benefit from natural resources are no different from those needed to attract inward FDI by MNEs, as well as build a viable domestic firm sector (Lall 1992, Criscuolo and Narula 2008, Narula and Dunning

\footnotetext{
${ }^{8}$ See Bruton (1998) for an excellent overview, and which forms the basis of the discussion on import substitution here.
} 
2010), and many of today's successful emerging economies were able to achieve this. These include a certain minimum level of infrastructure (including skilled and semiskilled human capital), functional markets (or organisations that can overcome market failures) to provide financial capital and other crucial support activities, stable institutions in the form of functional government agencies to ensure that these public goods are available to all economic actors fairly.

Not all countries invested in upgrading L advantages, or established the stable institutions necessary. In their absence, rents from natural resources were used for current consumption and wastefully dissipated. Weak governments also utilised resource rents to buy legitimacy. The existence or emergence of large resource rents can aggravate the feebleness of formal institutions, and this in turn means that resource rents are not deployed for development, but to extend the rule of autocratic and corrupt governments (Collier and O'Connell 2006).

\section{Act III: Extractive MNEs in the age of globalisation and liberalisation}

The end of the $20^{\text {th }}$ century saw the reversal of the import-substitution programmes, and replaced with a more export-oriented, outward-looking policy orientation that also rehabilitated the MNE. These policy changes saw a dramatic shift away from promoting manufacturing towards a comparative advantage-based approach. Intervention by host countries became less confrontational and more cooperative, as FDI has become part of the economic development plans of many countries. The need to negotiate and create incentives for MNEs was now a key aspect of policy. This led to a consequent shift in economic structure towards the primary sector, a growth in commodities exports, and shrinkage of secondary activities (Rodrik 2016). Much of the work on MNEs and economic development (see Narula and Dunning 2010 for a review, in addition to UNCTAD's World Investment Reports) has emphasised the role of spillovers and linkages from MNEs as the key to development.

Dramatic changes associated with globalisation have also seen important changes in the way in which MNEs organise their activities. There is a greater move away from full internalisation by firms (not just MNEs) towards non-equity and quasi-hierarchical governance of value chains that involve a network of actors. These developments have increased the potential for greater participation for host country actors than was previously 
the case. There are also new actors, in the form of large state-owned (or state-controlled) firms, and private MNEs from developing countries with the capital and resources to compete with the 'traditional' developed country MNEs. These firms are often the outcome of IS-era policies. Not all countries were able to build strong domestic actors. The nationalisation wave that typified developing countries during the IS-era did not always provide the social and economic benefits expected, especially in less developed nations (Barclay 2015). Weak stateowned actors were privatized, in some cases engaging with MNEs through joint ventures, in other cases sold in their entirety to MNEs.

There are today fewer monolithic MNEs that own all aspects (or even most) of the value chain and maintain their own infrastructure. The trend towards the use of non-equity modes has spread to the mining sector as well (Molina et al 2016). Although the extent to which the extractive sector has gone towards GVC-like structures varies considerably by firm, subsector and host country, there is a greater tendency to rely on specialised firms rather than their wholly-owned affiliates.

However, it would be wrong to assume that this led to a decreased influence of the MNE. Reduced ownership has not reduced their control. MNEs continue to exert considerable control as 'flagship' or 'lead' firms, but like lead firms in other GVC-friendly sectors, they are inclined to exert this control through non-equity mechanisms, either through outsourcing or through collaborative agreements (UNCTAD 2014, Narula and Wahed 2017, Kaplinsky et al 2011, Puck and Mullner, this issue).

A variety of enabling technologies have further assisted in enhancing the scope for the fragmentation of mining value chains. Activities that are easily codified such as logistics and transportation, warehousing, and so forth can now be outsourced. Specialised skills and heavy equipment (and their maintenance and operation) necessary can be leased from (or sub-contracted to) a variety of specialised actors. Where previously MNEs might have had to directly invest in designing and developing equipment, building infrastructure, and recruiting the necessary skilled specialists, these tasks can now be outsourced to specialised firms (Molina et al 2016). The extractive sector still has an oligopsonistic structure and the risk of opportunistic behaviour by external partners is minimal. However, the high capital intensity keeps the number of suppliers limited.

In terms of MNE-host country relations, there have been changes on both sides. Extractive MNEs have become conscious of their reputation for regulatory capture, and - perhaps 
because of the negative press from well-publicised (and disastrous) cases of extreme regulatory capture through regime change in Latin America and Africa- MNEs have sought to act with more consideration. Rent-sharing and contractual obligations negotiated between MNEs and nation states are more carefully observed, not only by the actors themselves but also by NGOs, supra-national institutions and stakeholders in the home country (Puck and Mullner, this issue).

Likewise, host countries are more aware of the need for monitoring the environmental and societal effects of extractive firms, and have at their disposal the expertise of a wide variety of expert advice. They are more uniformly engaged in ensuring that rents are accrued locally, by greater care in including (and monitoring) local content, taxes, repatriated profits.

Home countries less explicitly pursue the interests of their MNEs, with the possible exception of China. To the contrary, home country civil societies in developed countries can positively affect the environmental and social outcomes in their MNE overseas activity. MNEs are expected by pressure groups at home to constrain their activities to similar standards abroad, even where the host country does not require it (Zyglidopoulos et al this issue). Again, differences exist due to home country nationality - Canadian and European MNEs are more sensitive to home country social activism, while newer MNEs from developing countries (India, China, Russia) are less so. Engaging in CSR and entering local partnerships allow MNEs to enhance their organizational legitimacy in the host location, and as an important signal of their CSR credentials for other prospective host locations, as well as promoting good relations with civil society at home (for an interesting related discussion, see Buchanan and Marques, this issue).

A number of new large extractive industry MNEs from developing countries have strong home government ties, and in consequence are often still regarded as national champions. However, what is relevant to the present paper is that these new MNEs (both state-owned and formerly state-owned) have sought to internationalise, oftentimes relying on their de facto status as national champions. This permits them access to subsidised capital. Coupled with large subsoil reserves at home, these act as a substantial source of FSAs in their overseas expansion (Barclay 2015, Narula 2012).

Has the new dispensation improved the potential for sustainable development? 
The changes due to globalisation and liberalisation have increased the potential for linkages, both in terms of quantity and quality (Santangelo 2009). While the increased use of wider (and somewhat looser) types of governance has increased the potential for outsourcing and collaborative activities, depending upon the commodity and the institutional conditions of the host country. Large mining contractors like Theiss are able to take on all aspects of mining operations, or a single fragment. Others specialise in smaller, specialised segments, such as site construction or operating and maintaining equipment. In general, suppliers are firms with whom the flagship firm has a long extent relationship (Hanlin and Hanlin 2012). The extractive sector MNEs are much more capital-intensive, and high sunk costs of acquiring mineral rights must be written off gradually over decades and not years. While there are windfall rents on occasion, the boom-and-bust cycle means that over a 30 year period, returns over the lifetime of a mine may be small. It behoves them to work with partners whose organisations are closely aligned organisationally and culturally, and with whom there is a minimal risk of shirking (Hanlin and Hanlin 2012, Molina et al 2016). The high capital intensity and large scale needed to be a supplier are hard to achieve for most developing country firms (Farooki 2012, Kaplan 2012). Besides, MNEs now seek to develop global contracts, such that a single supplier provides inputs and services across all its operations globally.

Nonetheless, lead firms have strong incentives to identify new domestic suppliers (Adewuyi and Oyejide 2012). Many MNEs have dedicated supplier development programmes, either as part of their negotiated local content clauses, or their own CSR outreach efforts. Where inputs are highly codifiable, less strategic and do not require close coordination, lead firms may intentionally seek multiple and redundant alternative suppliers. Extractive activities also require location-specific knowledge, and need specialised equipment for specialised conditions.

By and large, opportunities for supplier firms from less developed countries are limited to support activities that do not require FSAs that derive from global presence and high capital intensity. These include accounting, health and safety, public and community relations, human resources management, marketing, quality control, and civil maintenance. Such activities require local knowledge and contacts, and generate consumption linkages (Fessehaie 2012, Teka 2012). 
There is space for domestic firms who can adapt or create efficiencies for a particular operation (Kaplan 2012, Molina et al 2016), and thereby generate production linkages. With some notable exceptions from Brazil, Peru, Chile, South Africa, China, Russia and India, there are few developing countries that have domestic firms capable of being original equipment manufacturers. This requires the capacity to engage in innovation through active $\mathrm{R} \& \mathrm{D}$, and this in turn requires a fairly robust innovation system to support this. Building up strong sectoral innovation systems requires a threshold level of tertiary educational establishments, research institutes, and functional institutions to link up with domestic and foreign economic actors. State programmes that link research institutes and financing with firms that have the opportunity and potential to upgrade their $\mathrm{O}$ advantages have been tried with a fair degree of success in the countries mentioned (Morris et al 2012, Figueiredo and Piana 2016, Kaplan 2012).

The post-IS era has - by and large - seen a decline in the quality of knowledge infrastructure and public goods in many developing countries, and a consequent decline in their $\mathrm{L}$ advantages. Adewuyi and Oyejide (2012) note that Nigeria's oil and gas sector has been fairly successful in building up domestic actors to participate with lead MNEs, due in part to Nigeria's investments in infrastructure and education during the 1960s and 1970s, and assisted by the import substitution programme that prevailed until the mid-1980s (Biersteker 2014). In the longer run, opportunities are likely to remain restricted to fiscal linkages and commodity linkages in the absence of a sturdy science and technology infrastructure.

\section{Conclusions: Looking to the future}

Although there are clearly greater opportunities for sustainable development through the astute use of linkages and rents, this is not an easy path to follow. High rents during a commodity boom are often easily disbursed on a variety of political and economic priorities. The most recent commodity boom driven by Chinese demand for resources since the beginning of the $21^{\text {st }}$ century has also been followed by a downturn since about 2013. Despite fairly good governance, infrastructure and institutions, much of Latin America has failed to invest in building up either their national absorptive capacity, or the competitiveness of their home-grown firms. Weak location advantages - especially those associated with the knowledge infrastructure - are victims of systematic neglect and underinvestment in much of sub-Saharan Africa and Latin America, creating an uneven quality of human capital. The retreat of the vertically integrated MNE that dominated the sector during much of the $20^{\text {th }}$ 
century has not necessarily led to greater local embeddedness and production linkages. Both lead MNEs and major mining contractors are keen to increase local content and local suppliers, and to help existing suppliers upgrade. However, finding new suppliers/replacing existing suppliers happens only gradually (Pietrobelli and Saliola 2009), and systemic weaknesses in the formal firm sector limits substantial local linkage formation (Pietrobelli and Staritz 2013). The countries that have the capacity for increased linkages are those that were more successful in the import substitution era, building the appropriate infrastructure to support the firm sector that came out of this period. Unfortunately, only a small subset of new actors has survived the exposure to international competition over the last three decades, and there have been few new entrants subsequently.

New extractive MNEs from emerging economies has altered the market in the extractive industries, but it is not evident that they generate greater linkages. Fessehaie (2012) notes the considerable differences in the way in which Chinese and Indian MNEs engage with suppliers in Zambia. For instance, Chinese MNEs showed a preference for Chinese suppliers and demonstrated little interest in embedding themselves locally; the Indian MNE showed little supplier loyalty and was overly price conscious. Unlike the South African and North American firms, neither the Indians nor Chinese were interested in fostering supplier upgrade programmes. Indeed, Chinese MNEs have shown a predilection to develop enclaves, bringing in Chinese workers, and Chinese suppliers, even where local suppliers are readily available, especially in Africa. This has led to a degree of crowding out, especially in construction and infrastructure.

By and large, upgrading through linkages has been largely limited to fiscal and consumption linkages. Developing deeper linkages - whether in the extractive sector or any other - is a long term initiative. Linkages requires embedding, which in turn requires stability of policies and institutions, and investment in knowledge capital (Giuliani et al 2005, Figueiredo and Piana 2016)). Rents are accrued by those who control the knowledge capital, but it requires capital to beget capital. Indeed, knowledge capital can be said to be scarcer than financial capital, and it must be nurtured.

As Kaplinsky et al (2011) emphasise, sustainable development requires developing new sectors less reliant on exhaustible resources, and the expansion of inter-industry linkages. However, in much of the developing world, the extractive sector maintains an enclave-like character; Countries that avoided the resource curse carefully nurtured inter-industry 
linkages, and deliberately sought to avoid over-specialisation. Marin et al (2015) point to the recent success of Argentina and Chile in leveraging their natural resources to build up new industries that are more 'future-proof'. However, horizontal linkages require long-term sustained and orchestrated policies, and cannot be foisted on the MNE. Inter-industry linkages are hard to mandate as part of a local content policy, which are likely only to strengthen vertical linkages. Venables (2016) notes that policies on their own have 'generally not led to transformative growth of new activities'. Linkage creation needs to be effectively managed and promoted, and this requires a long-term view and hands-on engagement with both MNEs and domestic actors.

\section{Implications for theory}

Internationalisation by definition requires non-location-bound $\mathrm{O}$ advantages. Firms that do not have equivalent $\mathrm{O}$ advantages to the market leaders in successfully organising and participating in complex cross-border hierarchies and networks are rarely able to survive in the long run. Managing large scale MNEs requires other higher-order $\mathrm{O}$ advantages, such as the ability to achieve economies of common governance. Such O advantages are hard to acquire through M\&A, as the knowledge is firm-specific and difficult to codify and transfer. Much has been commented upon about the rise of MNEs from emerging economies. Several of these EMNEs, particularly those from Brazil, China, Russia, South Africa and India have expanded rapidly internationally through M\&A. While these firms may have the technological and financial assets to expand abroad, it is not always obvious whether they are able to capture economies from common governance. In addition, their lack of experience in foreign markets means that they are likely to replicate practices that are effective at home, but less effective elsewhere.

Beyond the 'traditional' $\mathrm{O}$ advantages discussed in this paper, a new and important higher order $\mathrm{O}$ advantage that is increasingly critical in this sector is the capacity to be socially and environmentally responsible. This goes beyond CSR practices. Zyglidopoulos et al (this issue) point to the need to have a 'social license to operate' from local communities, in addition to legal rights from the state. Acquiring such a 'social license' is a matter of experience, and by its very nature is a location-specific advantage. It is worthy of note that MNEs with considerable success at home in Canada (for instance) at engaging with local communities and being socially and environmentally responsible, are unable to translate such success abroad. This reflects the location-boundedness of such knowledge. Not all MNEs are 
able to translate knowledge from one location to another, because all knowledge to some extent is sticky and context-specific. The idiosyncratic nature of every project means that being good at engaging with local communities (and their expectations) in one location does not necessarily help in a new location or country. In other words, there are no scale economies in CSR. 
Adewuyi, A. O., \& Oyejide, T. A. (2012). Determinants of backward linkages of oil and gas industry in the Nigerian economy. Resources Policy, 37(4), 452-460.

Barclay, L. A. (2015) Managing FDI for Development in Resource-Rich States: The Caribbean Experience, Basingstoke, Palgrave Macmillan.

Biersteker, T. J. (2014). Multinationals, the State and Control of the Nigerian Economy. Princeton University Press.

Bruton, H. (1998) 'A Reconsideration of Import Substitution', Journal of Economic Literature, vol 36, pp. 903-36.

Buchanan, S. and Marques, $\mathbf{J}$ (this issue) The role of home country industry associations in shaping MNE international CSR Practice, Journal of World Business, this issue

Collier, Paul and Stephen A. O'Connell (2006), "Opportunities and Choices," Chapter 2 in B. Ndulu, S. O'Connell, R. Bates, P. Collier, and C. Soludo, eds, The Political Economy of Economic Growth in Africa, 1960-2000, Cambridge University Press

Criscuolo, P., \& Narula, R. (2008). A novel approach to national technological accumulation and absorptive capacity: aggregating Cohen and Levinthal, The European Journal of Development Research, 20(1), 56-73.

Dantas, E., \& Bell, M. (2011). The co-evolution of firm-centered knowledge networks and capabilities in late industrializing countries: the case of Petrobras in the offshore oil innovation system in Brazil. World Development, 39(9), 1570-1591.

Dunning, J. H. (1993), Multinational Enterprises and the Global Economy, Addison-Wesley, Wokingham, UK.

Dunning, J. H., \& Narula, R. (1996). Foreign direct investment and governments: Catalysts for economic restructuring. London: Routledge.

Farooki, M. (2012). The diversification of the global mining equipment industry-Going new places? Resources Policy, 37(4), 417-424.

Fessehaie, J. (2012). What determines the breadth and depth of Zambia's backward linkages to copper mining? The role of public policy and value chain dynamics. Resources Policy, $37(4), 443-451$.

Figueiredo, P.N., Piana, J., (2016) When "one thing (almost) leads to another": A micro-level exploration of learning linkages in Brazil's mining industry. Resources Policy, 49, 405-414

Giroud, A. (2012). Mind the gap: How linkages strengthen understanding of spillovers. The European Journal of Development Research, 24(1), 20-25. 
Girvan, N. (1970). Multinational corporations and dependent underdevelopment in mineralexport economies. Social and Economic Studies, 490-526.

Girvan, N. (1973). The development of dependency economics in the Caribbean and Latin America: Review and comparison. Social and Economic Studies, 1-33.

Giuliani, E, Pietrobelli, C \& Rabellotti, R. 2005. Upgrading in global value chains: Lessons from Latin American clusters, World Development, 33, pp. 549-573.

Hanlin, R., \& Hanlin, C. (2012). The view from below: 'lock-in'and local procurement in the African gold mining sector. Resources Policy, 37(4), 468-474.

Harding, T., \& Venables, A. J. (2016). The implications of natural resource exports for nonresource trade. IMF Economic Review, 64(2), 268-302.

Hirschman, A. O. 1958. The strategy of economic development Vol. 10. New Haven: Yale University Press.

Hirschman, A. O. 1977, 'A Generalised Linkage Approach to Development, with Special Reference to Staples', in M. Nash (ed.) Essays on Economic Development in Honour of Bert F. Hoselitz, Chicago University Press, Chicago, IL, pp. 67-98.

Hirschman, A. O. 1981, Essays in Trespassing: Economics to Politics and Beyond, Cambridge University Press, New York.

IFC (International Finance Corporation). (2013). IFC Jobs Study: Assessing Private Sector Contributions to Job Creation and Poverty Reduction. Washington D.C.

Jindra, B., Giroud, A., \& Scott-Kennel, J. (2009). Subsidiary roles, vertical linkages and economic development: Lessons from transition economies. Journal of World Business, 44(2), 167-179.

Jones. G. (2005). Multinationals and global capitalism. Oxford: Oxford University Press, 2005.

Kaplan, D. (2012). South African mining equipment and specialist services: Technological capacity, export performance and policy. Resources Policy, 37(4), 425-433.

Kaplinsky, Raphael; Morris, Mike and Kaplan, Dave (2011). A Conceptual Overview to Understand Commodities, Linkages and Industrial Development in Africa. Africa Export Import Bank.

Kraemer, R., \& van Tulder, R. (2009). Internationalization of TNCs from the extractive industries: a literature review. Transnational Corporations, 18(1), 137.

Lall, S. (1992). Technological capabilities and industrialization. World Development, 20(2), 165-186. 
Levitt, K. and Best, L. (1975) 'Character of the Caribbean Economy', in G.L. Beckford (ed.) Dependence and Backwards, Institute of Social and Economic Research, University of the West Indies, Mona, Jamaica.

Lewis, W. A. (1954). Economic Development with Unlimited Supplies of Labour. The Manchester School, 22(2), 139-191.

Luxemburg, R. (2003). The accumulation of capital, Routledge, London.

Marin, A., Navas-Alemán, L., \& Perez, C. (2015). Natural resource industries as a platform for the development of knowledge intensive industries, Tijdschrift voor economische en sociale geografie, 106(2), 154-168.

Molina, O., Olivari, J., \& Pietrobelli, C. (2016). Global Value Chains in the Peruvian Mining Sector. Inter-American Development Bank.

Moran, T. (1978). Multinational Corporations and Dependency: A Dialogue for Dependentistas and Non-Dependentistas. International Organization, 32(1), 79-100.

Morris, M., Kaplinsky, R., Kaplan, D., 2012. One thing leads to another - Commodities, linkages and industrial development. Resources Policy 37 (4), 408-416.

Narula, R. (2012). Do we need different frameworks to explain infant MNEs from developing countries? Global Strategy Journal, 2(1), 41-47.

Narula, R. (2015). The viability of sustained growth by India's MNEs: India's dual economy and constraints from location assets, Management International Review, 55:191-205.

Narula, R., \& Dunning, J. H. (2010). Multinational enterprises, development and globalization: Some clarifications and a research agenda. Oxford Development Studies, 38(3), 263-287.

Narula, R., \& Santangelo, G. (2012). Location and collocation advantages in international innovation. Multinational Business Review, 20(1), 6-25.

Narula, R., \& Wahed, M. (2017). The Dominant Presence of MNES in Agro-Food GVCs: Implications for the Developing Countries, In Food Security and Sustainability. Springer International Publishing, (pp. 71-88)

Pietrobelli, C., \& Saliola, F. (2008). Power relationships along the value chain: multinational firms, global buyers and performance of local suppliers. Cambridge Journal of Economics, 32(6), 947-962.

Pietrobelli, C., \& Staritz, C. (2013). Challenges for global value chain interventions in Latin America. Inter-American Development Bank.

Prebisch, R. (1950) The Economic Development of Latin America and its Principal Problems. United Nations: New York. 
Puck, J. \& Mullner, J. (this issue). Towards a Holistic Framework of MNE-State Bargaining: A Formal Model and Case-based Analysis. Journal of World Business (this issue)

Rasiah, R. (1995). Foreign capital and industrialization in Malaysia. Springer.

Rodney, W. (1972). How Europe underdeveloped Africa. London: Bogle-L'Ouverture Publications

Rodrigues, S. B. \& Dieleman, M. (this issue). The Internationalization Paradox: Untangling dependence in Multinational State Hybrids. Journal of World Business (this issue)

Rodrik, D. (2016). Premature deindustrialization. Journal of Economic Growth, 21(1), 1-33.

Sachs, Jeffrey, and Andrew M. Warner. 1995. "Natural Resource Abundance and Economic Growth.” NBER Working Paper 5398.

Sachs, Jeffrey, and Andrew Warner. 1997. "Sources of Slow Growth in African Economies." Journal of African Economies 6(3): 335- 76.

Santangelo, G. D. (2009). MNCs and linkages creation: Evidence from a peripheral area. Journal of World Business, 44(2), 192-205.

Shapiro, D, Hobdari, B. and Oh, C-H (this issue) Natural Resources, Multinational Enterprises and Sustainable Development, Journal of World Business (this issue)

Singer, H. W. (1950). The distribution of gains between investing and borrowing countries. American Economic Review, 40(2), 473-485.

Teka, Z. (2012). Linkages to manufacturing in the resource sector: The case of the Angolan oil and gas industry. Resources Policy, 37(4), 461-467.

UNCTAD (2007) World Investment Report, UN, Geneva

UNCTAD (2014) World Investment Report, UN, Geneva

Venables, Anthony 2016. "Using Natural Resources for Development: Why Has It Proven So Difficult?" Journal of Economic Perspectives, 30(1): 161-84.

Ville, S., \& Wicken, O. (2012) The dynamics of resource-based economic development: evidence from Australia and Norway, Industrial and Corporate Change, 22(5), 1341-1371.

World Bank (2011) The Changing Wealth of Nations: Measuring Sustainable Development in the New Millennium, World Bank, Washington, DC.

Yakovleva, N. \& Vazquez-Brust, D. A. (this issue). Mining multinational enterprises and artisanal small-scale miners: from confrontation to cooperation. Journal of World Business (this issue). 
Zyglidopoulos, S., Symeou, P. \& Williamson, P. (this issue). Internationalization as a driver of the corporate social performance of extractive industry firms. Journal of World Business (this issue). 
Table 1 Resource dependence, selected countries

\begin{tabular}{|c|c|c|c|c|c|c|c|c|c|c|}
\hline \multirow[b]{2}{*}{ Sorted by GDP } & \multicolumn{2}{|l|}{1980} & \multicolumn{2}{|l|}{1990} & \multicolumn{2}{|l|}{2000} & \multicolumn{2}{|l|}{2010} & \multicolumn{2}{|l|}{2015} \\
\hline & \begin{tabular}{|l|}
$\mathrm{NR}$ \\
exports/tota \\
$1 \quad$ exports \\
$(\%)$
\end{tabular} & $\begin{array}{l}\text { NR rents } \\
\text { as \% of } \\
\text { GDP }\end{array}$ & $\begin{array}{l}\text { NR } \\
\text { exports/to } \\
\text { tal exports }\end{array}$ & $\begin{array}{l}\text { NR rents } \\
\text { as \% of } \\
\text { GDP }\end{array}$ & $\begin{array}{l}\mathrm{NR} \\
\text { exports/tot } \\
\text { al exports } \\
(\%)\end{array}$ & $\begin{array}{ll} & \\
\text { NR rents } \\
\text { as \% of } \\
\text { GDP }\end{array}$ & \begin{tabular}{|l|}
$\mathrm{NR}$ \\
exports/tot \\
al exports \\
$(\%)$
\end{tabular} & $\begin{array}{l}\text { NR rents } \\
\text { as \% of } \\
\text { GDP }\end{array}$ & $\begin{array}{l}\text { NR } \\
\text { exports/tot } \\
\text { al exports }\end{array}$ & $\begin{array}{l}\text { NR rents } \\
\text { as \% of } \\
\text { GDP }\end{array}$ \\
\hline Brazil & 9 & 2.7 & 10 & 2.2 & $8 \%$ & 2.5 & $26 \%$ & 4.5 & $19 \%$ & 2,9 \\
\hline Canada & 10 & 9.0 & 10 & 3.1 & $11 \%$ & 4.5 & $22 \%$ & 2,8 & $19 \%$ & 0,9 \\
\hline Australia & 15 & 6.2 & 25 & 3,3 & $21 \%$ & 2.6 & $50 \%$ & 9.6 & $45 \%$ & 4,8 \\
\hline Nigeria & 83 & 34.6 & 93 & 50,4 & $94 \%$ & 38.2 & $85 \%$ & 13.8 & $87 \%$ & 4,7 \\
\hline Norway & 47 & 7.6 & 41 & 7,9 & $58 \%$ & 11.5 & $56 \%$ & 7.7 & $51 \%$ & 5,4 \\
\hline South Africa & 22 & 15.1 & 15 & 6,0 & $17 \%$ & 2.9 & $24 \%$ & 7.7 & $20 \%$ & 4,2 \\
\hline Malaysia & 25 & 37.1 & 18 & 25,7 & $7 \%$ & 9.8 & $11 \%$ & 8.4 & $9 \%$ & 4,8 \\
\hline Colombia & 0.5 & 4,5 & 29 & 7.3 & $35 \%$ & 5.1 & $48 \%$ & 6.3 & $52 \%$ & 3,6 \\
\hline Chile & 15 & 9,1 & 11 & 11.6 & $16 \%$ & 6,9 & $24 \%$ & 18,2 & $26 \%$ & 12,2 \\
\hline
\end{tabular}

Source: CHELEM and The World Bank, various databases

Note: Total natural resources rents are the sum of oil rents, natural gas rents, coal rents (hard and soft), mineral rents, and forest rents. The estimates of natural resources rents are calculated as the difference between the price of a commodity and the average cost of producing it. 